\title{
Composting of Corn By-Product using EM4 and Microorganism Azotobacter sp. as Composting Organism
}

\section{Nuniek Hendriani, Sri Rachmania Juliastuti, Hamida Nuur Masetya, and Imam Tianto Aditiyas Saputra}

Department of Chemical Engineering, Institut Teknologi Sepuluh Nopember, Kampus ITS Sukolilo Surabaya 60111, Indonesia

\section{Abstract}

Nowadays the organic compost is very important for farmers because of its environmentally friendly character. However, the production technology of organic compost is not well-known yet for the farmers. This study aimed to utilize corn byproduct compost as fertilizer for plants growth. Composting process was accelerated by addition of composting organism called as effective microorganism (EM4) and Azotobacter. Their composition were EM4:Azotobacter 1:1; 1:3, EM4 alone, Azotobacter alone and without addition of composting microorganism. The composting process was conducted in a composter for $15 \mathrm{~d}$ and mixed three times per day. The process should be carried out under controlled aerobic conditions. The observed parameters were carbon $(C)$, nitrogen $(N)$, phosphor $(P)$, and potassium $(K)$ content. The parameters was measured before and after composting process. The resulted compost were applied to the growing corns, chilis, and tomatoes as fertilizer. The result showed that the best compost was obtained on 3:1 composition of EM4 : Azotobacter. This composition was able to reduce $0.74 \%$ carbon content, and increase $151.46 \%, 147.9$ $\%$, and $238.42 \%$ of $\mathrm{N}, \mathrm{P}, \mathrm{K}$ content respectively. Moreover this particular compost was able to bring $3.75 \mathrm{~mm}$ corn stem and $1.0 \mathrm{~mm}$ corn leaf growth per day, lead to harvesting of two tomatoes and eight chilie

Keywords: Azotobacter, compost, corn by-product, EM4.

\section{Introduction}

Selection and Peer-review under the responsibility of the NRLS Conference Committee.

\section{G OPEN ACCESS} on fertilizers. This situation causes many negative effects, especially for environmental pollution.Therefore, we need an effort to improve the use of fertilizers as efficiently as possible and environmentally friendly. The effort that can overcome mind's problem is by using organic fertilizer, known as compost. Organic agriculture has refund system which enables the return of all generated organic matters into the ground [1].

Compost is a complete fertilizer that contains macro and micro nutrients needed by plants and environmentally friendly. Compost is composed of organic matters 
decomposes, both of plants and animals. With the availability of materials for compost and the improvement of farmer's skill in agricultural by-product process as compost, then the fertilizers needed will be available and the cost is cheaper. From any raw materials for compost, corn by-product is the one that has a great potential. Corn (Zeo mays L.), is one of the world's most important food crops. The production of corn in East Java in 2013 was $5.71 \times 10^{6} \mathrm{t}$ [2].

The production of organic crop waste from corn is large enough. If the waste is not used, it will make the environment polluted. But, the use of corn by-product is not optimal since it has an abundant number. Corn by-products, like other organic waste, they contain carbon (C) which will be decomposed by microorganism during the composting process. Carbon is a substance which is needed by microorganism to grow and proliferate. So the corn by-product can be reused as compost by composting process.

However, the organic matters cannot be directly used because the comparison of $\mathrm{C} / \mathrm{N}$ is still relatively high. The plants can use organic matters that has $\mathrm{C} / \mathrm{N}$ ratio which has a range value between 15 to 25 . So, the corn by-product should be decomposed by microorganism as decomposers [3].

The use of microorganisms in the composting process will improve the quality of the produced compost, reduce the ratio of the volume of the produced waste, reduce the farmer's dependence of chemical fertilizers, improve the efficiency of the agricultural, and will indirectly increase the farmer's income [1]. In this study, the produced compost will be tested to corns, chilies, and tomatoes fertilizers. Corn, chili, and tomato can be planted from their seeds, so there are nurseries needed.

\section{Material and Method}

Materials which are needed for this study are corn by-product, Azotobacter sp., and EM4. Then the tools which are needed are composter, aerator, weight, and pH paper.

The corn by-product is the corn's leaves, husks, and stems which unused postharvest. This corn by-products are used as raw materials resized up to $1 \mathrm{~cm}$. Raw materials are analyzed for the content of Carbon $(C)$, Nitrogen $(N)$, phosphor $(P)$, and Potassium (K) before the composting process. Then the corn by-product conducted in a rotary drum composter with the addition of Azotobacter and EM 4 activator according to predefined variables for composting process. The rotary drum composter flows by air as $14 \mathrm{~L}$ per min per variables by aerator to supports the aerobic process. Temperature and $\mathrm{pH}$ measurements are take once daily for $15 \mathrm{~d}$ the composting process. Agitator in the rotary drum composter is rotates three times a day until the compost produces, each agitator rotated 15 times at one time. After the compost produced, then analized 


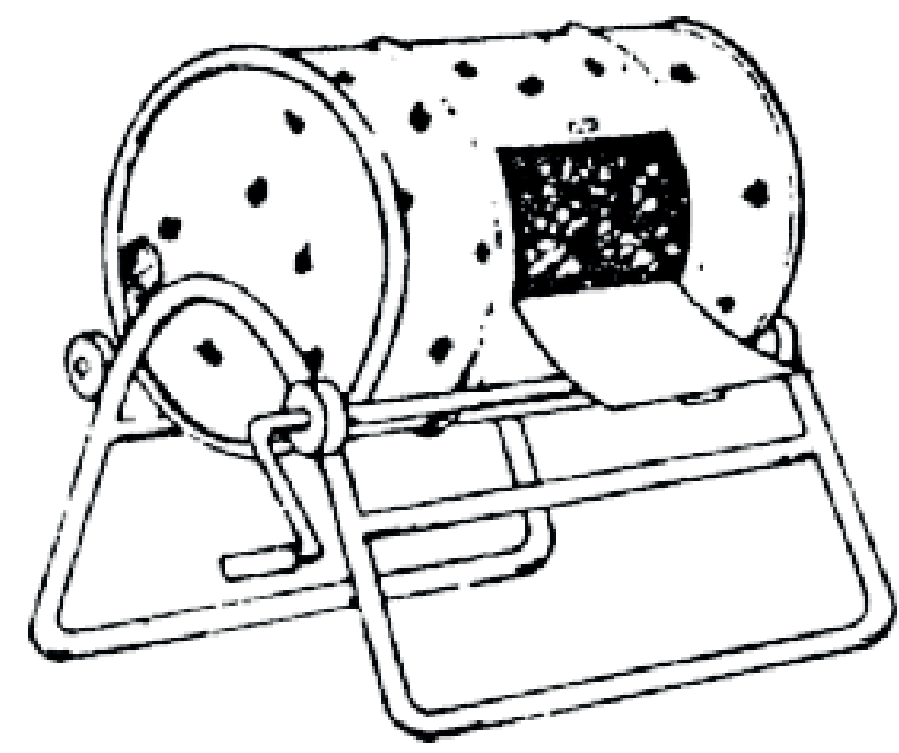

Figure 1: Rotary Drum Composter.

Variabels
Standart (Permentan 2009)
Raw Materials
EM-4 100\%
EM4 : Azotobacter (1:1)
EM4 : Azotobacter (1:3)
EM4 : Azotobacter (3:1)
Azotobacter 10o \%
Without Microorganism

\begin{tabular}{|c|c|c|c|c|}
\hline \multicolumn{5}{|c|}{ Parameters } \\
\hline $\mathbf{C}(\%)$ & $\mathbf{N}(\%)$ & $\mathbf{C} / \mathbf{N}$ Rasio & $\mathbf{P}(\%)$ & $\mathbf{K}(\%)$ \\
\hline$>12 \%$ & $<6 \%$ & 15 to 25 & $<6 \%$ & $<6 \%$ \\
\hline $28.4 \%$ & $0.85 \%$ & $33.21 \%$ & $0.34 \%$ & $0.196 \%$ \\
\hline $24.44 \%$ & $1.46 \%$ & 16.74 & $0.42 \%$ & $0.26 \%$ \\
\hline $26.38 \%$ & $2.05 \%$ & 12.86 & $1.09 \%$ & $0.53 \%$ \\
\hline $27.13 \%$ & $1.79 \%$ & 15.15 & $1.44 \%$ & $0.45 \%$ \\
\hline $28.19 \%$ & $2.15 \%$ & 13.11 & $0.86 \%$ & $0.66 \%$ \\
\hline $26.07 \%$ & $1.91 \%$ & 13.65 & $0.44 \%$ & $0.33 \%$ \\
\hline $25.64 \%$ & $0.93 \%$ & 27.57 & $0.37 \%$ & $0.22 \%$ \\
\hline
\end{tabular}

TABLE 1: The content datas of C, N, C/N Rasio, P, and K.

the content of Carbon $(C)$, Nitrogen $(N)$, phosphor $(P)$, and Potassium (K) from each variabels of composts.

After the composting process is complete, the compost will be given to chillies, tomatoes, and corns for each variable. Then, the next step is to measure the height of plants for chillies, tomatoes, and corns every $2 \mathrm{~d}$ for $20 \mathrm{~d}$ after the compost have been given. In addition, we calculate the amount of the harvesting chilies and tomatoes after $20 \mathrm{~d}$ after the compost have been given.

\section{Results and Discussion}

Table 1 shows that the content of organic carbon, organic nitrogen, phosphor, and potassium of composts for all added variables of activator eligible with the quality 


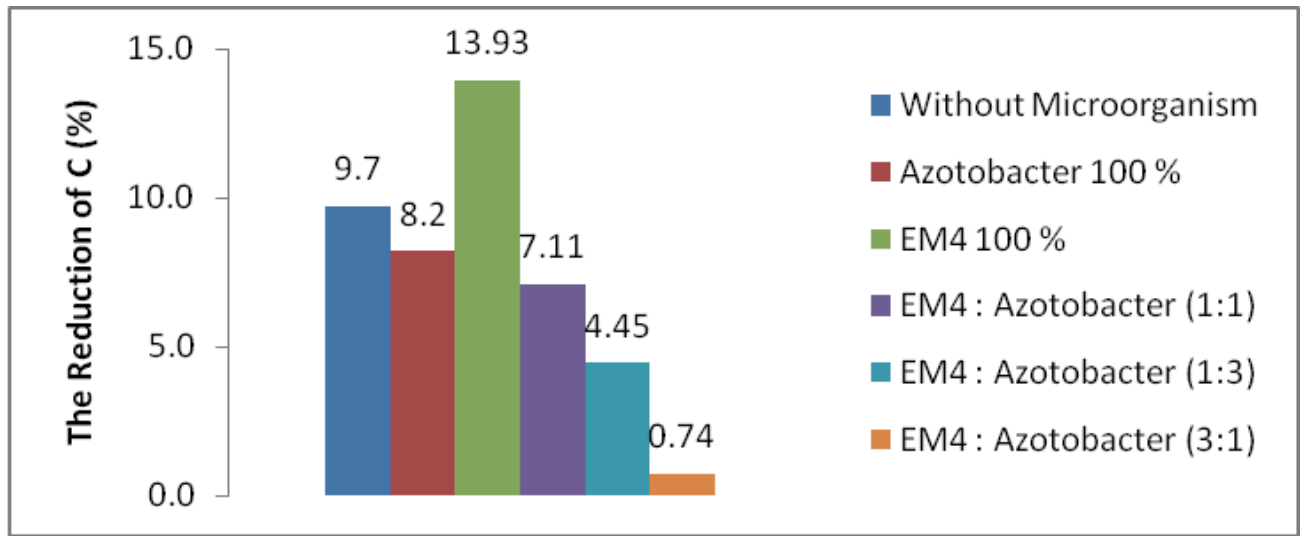

Figure 2: The reduction of organic carbon (\%) after composting process.

standards based on 'Peraturan Pertanian R.I' (Agriculture Regulation of Republic Indonesia) is more than $12 \%$ of $\mathrm{C}$ and less than $6 \%$ of $\mathrm{N}, \mathrm{P}$, and $\mathrm{K}$ for solid compost. But for C/N Ratio data, only the quality of composts for EM4 $100 \%$ is equal to 16.74 and 1:3 (v/v) Azotobacter:EM4 is equals to 15.15 which are eligible with the quality standards based on 'Peraturan Pertanian R.I' which has range value 15 to 25 for solid compost [3].

\subsection{Organic Carbon (C)}

Figure 2 shows the reduction of organic carbon content (C) after $15 \mathrm{~d}$ composting process for each variables. Figure 2 shows the largest red suction of organic carbon contain (C) is at EM4 $100 \%$ added in the amount of $13.93 \%$. The lignin content of corn by-product is high enough. The presence of lignin causes microorganism difficult to decompose $C$ which contain in the cellulose. One of the microorganisms contained in the microorganism's culture EM4 is lactic acid which can reduce lignin and cellulose to be more easily decomposed. So the microorganism more can easily decompose $C$ and cause the reduction of the content of $C$.

\subsection{Organic Nitrogen (N)}

Figure 3 presents the increment of organic nitrogen content $(N)$ after $15 \mathrm{~d}$ composting process for each variables. Figure 4 shows the largest increment of organic carbon nitrogen $(\mathrm{N})$ is at 3:1 (v/v) EM4:Azotobacter which is equal to $151.46 \%$. although at this variable the amount of Azotobacter which act as a nitrogen fixing is not much enough, but the compost has the largest increment. It shows that the microorganism in this variable can decompose $C$ easily which is needed by microorganism to grow and proliferate. With the large consumption of $C$, then the nitrogen fixing bacteria that exist can proliferate rapidly and is able to bind more nitrogen. 


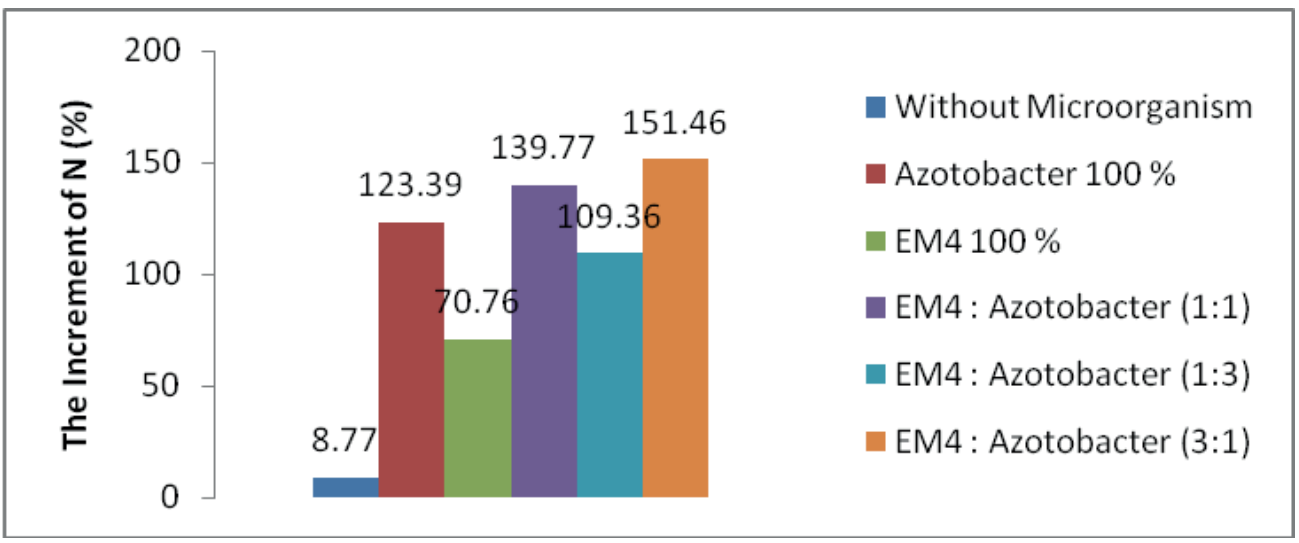

Figure 3: The increment of organic nitrogen (\%) after composting process.

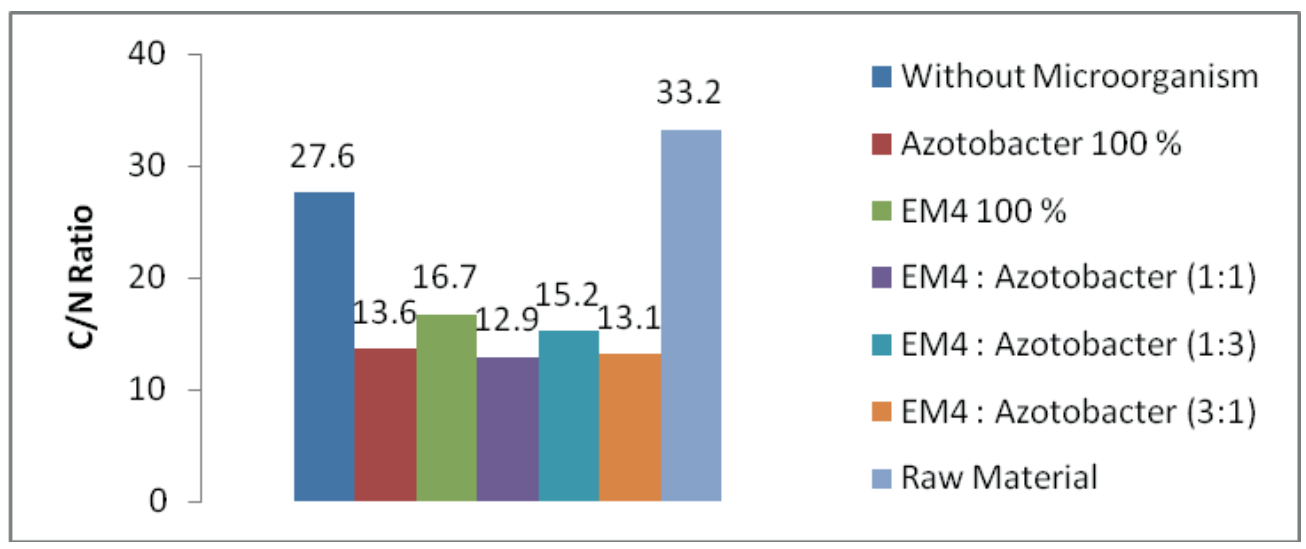

Figure 4: C/N Ratio Graph.

\subsection{C/N Ratio}

Figure 4 portrays the $\mathrm{C} / \mathrm{N}$ Ratio after $15 \mathrm{~d}$ composting process for each variables. That is can showed from initial C/N Ratio at raw material which had changes after $15 \mathrm{~d}$ composting process on each added variables of activator.

\subsection{Phosphor (P)}

Figure 5 points out the increment of phosphor content $(P)$ after $15 \mathrm{~d}$ composting process for each variable. This can be seen from initial content of $P$ at raw material which had changed after $15 \mathrm{~d}$ composting process on each added variables of activator.

Figure 5 shows the largest increment content of phosphor $(P)$ at 1:3 $(\mathrm{v} / \mathrm{v})$ of EM4: Azotobacter that is equals to $317.46 \%$. Although the EM4 addition which contain phosphate solublizing bacteria is quite a bit, this variable shows the largest content of $\mathrm{N}$ and $\mathrm{C}$ consumptions so the phosphate solublizing bacteria can proliferate rapidly. The number of microorganism derived from microbial metabolic activity increase the size of cells that consume carbon so they proliferate more rapidly. Then, the phosphate 


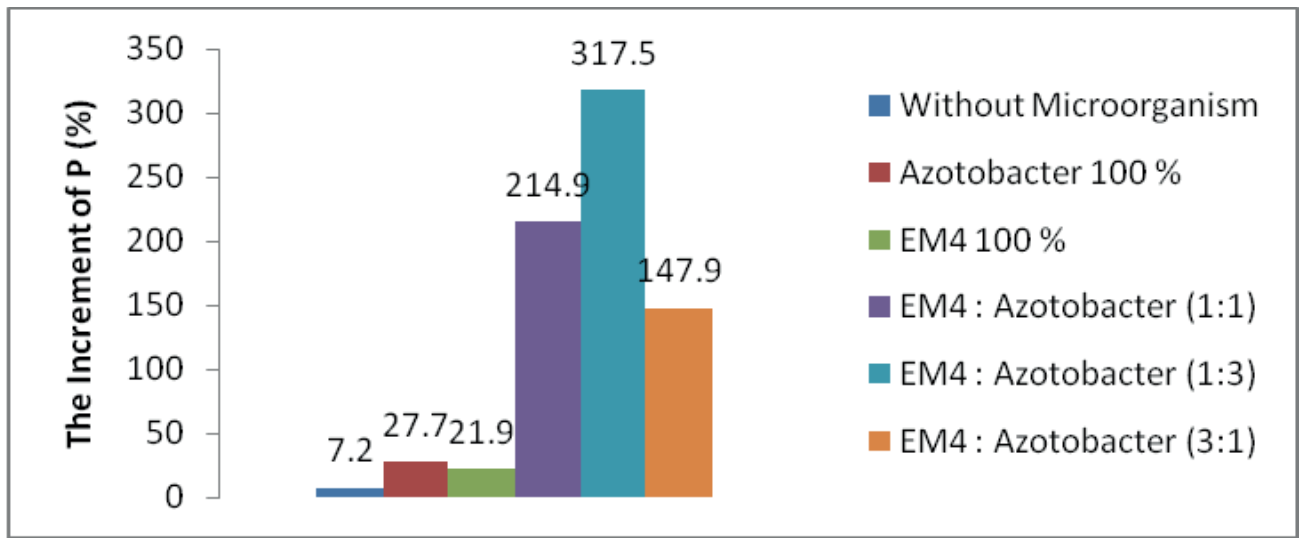

Figure 5: Graphic of the increment of phosphor (\%) after composting process .

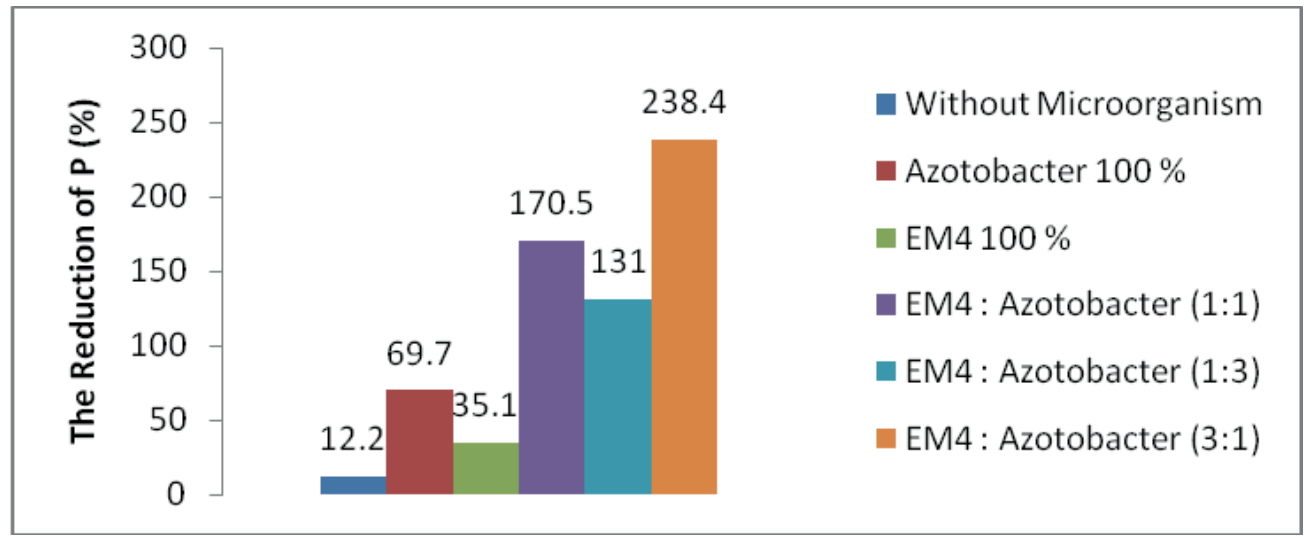

Figure 6: The increment of potassium (\%) after composting process.

solublizing bacteria will increase with the metabolism of microorganism or by the addition of activators. This is consistent with literature review indicating that along with the composting process, the content of phosphate will increase. [4].

\subsection{Potassium (K)}

In Figure 6 appear the increment of potassium content (K) after $15 \mathrm{~d}$ composting process for each variables. That is can showed from initial content of $K$ at raw material which had changes after $15 \mathrm{~d}$ composting process on each added variables of activator.

Figure 6 shows that the largest increment of potassium (K) at 3:1 (v/v) EM4: Azotobacter is equal to $238.42 \%$. It shows that the addition of EM4 and Azotobacter can increase the best content of potassium. It is caused by potassium solublizing bacteria (Bacillus mucilaginous) which is contain at $\mathrm{EM}_{4}$ so can increase the content of $\mathrm{K}$ in the compost. The content of potassium will increase with the metabolism of microorganism or by addition of activator. The mixture of Azotobacter and EM4 will be a better combination to increase the content of potassium. This is consistent with 


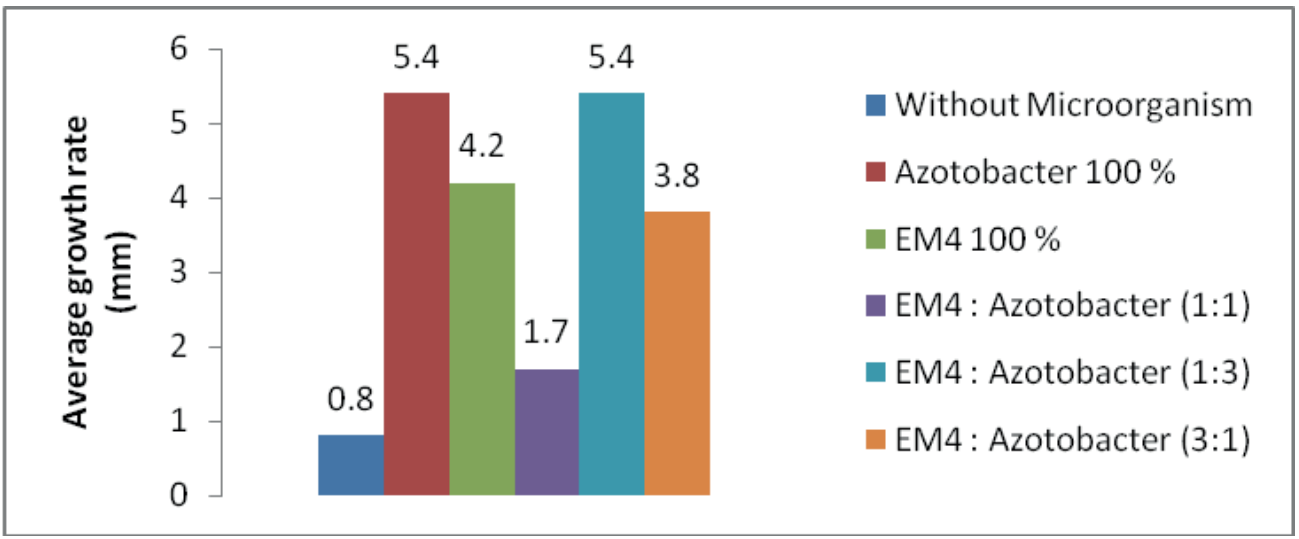

Figure 7: Graphic of the average growth rate of the Corn's Stem for $20 \mathrm{~d}$.

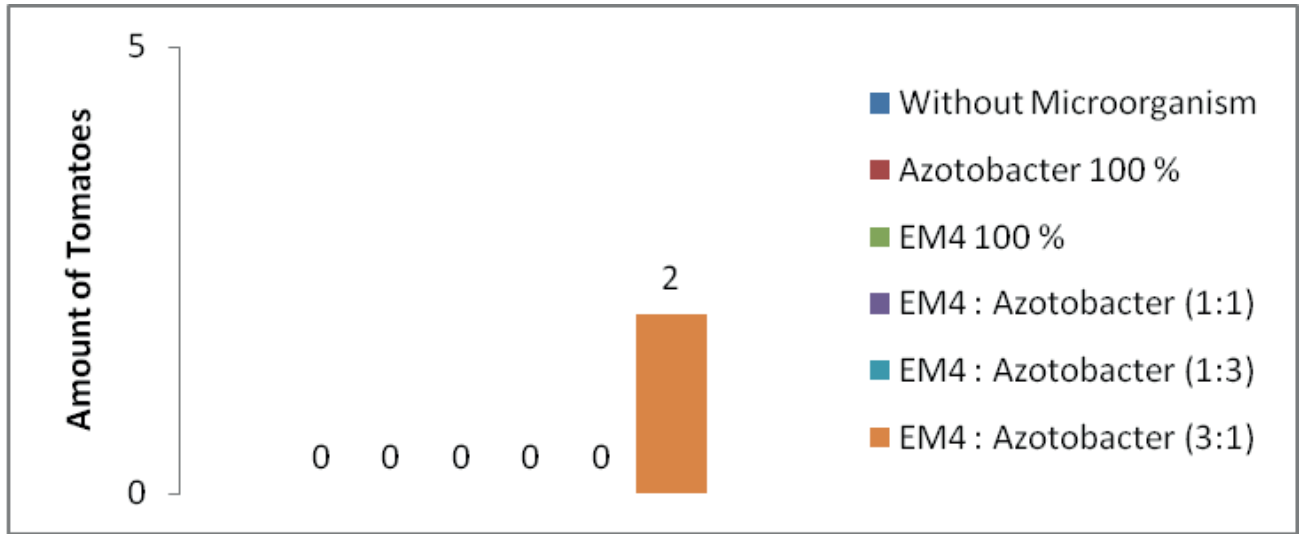

Figure 8: Graphic of the ammount of harvested tomatoes for $20 \mathrm{~d}$.

literature review that along with the composting process, the content of potassium will increase [4].

\subsection{The Growth Rate of Corn, Tomatoes, and Chillies}

There is the comparison between an additional variable of EM4 activator and Azotobacter from the length stalks of corn for $20 \mathrm{~d}$ after being given by the compost:

Figure 7 shows the highest average growth rate of stem on corn given by compost with variable 1:3 (v/v) EM4:Azotobacter which equals to $5.4 \mathrm{~mm}$ per day.

Test result on the plant is consistent with the result of data of the content analysis of $\mathrm{N}$ and $\mathrm{P}$ which contains the largest nitrogen and phosphor. The given compost containing $N$ and $P$ can increase the plant growth. Nitrogen is a major nutrient for plant growth, which is very important for the growth of plant such as leaves, stems, and roots [4].

The comparison between an additional variable of EM4 activator and Azotobacter from the amount of harvested tomatoes for $20 \mathrm{~d}$ after being given by the compost can be seen in the following. 


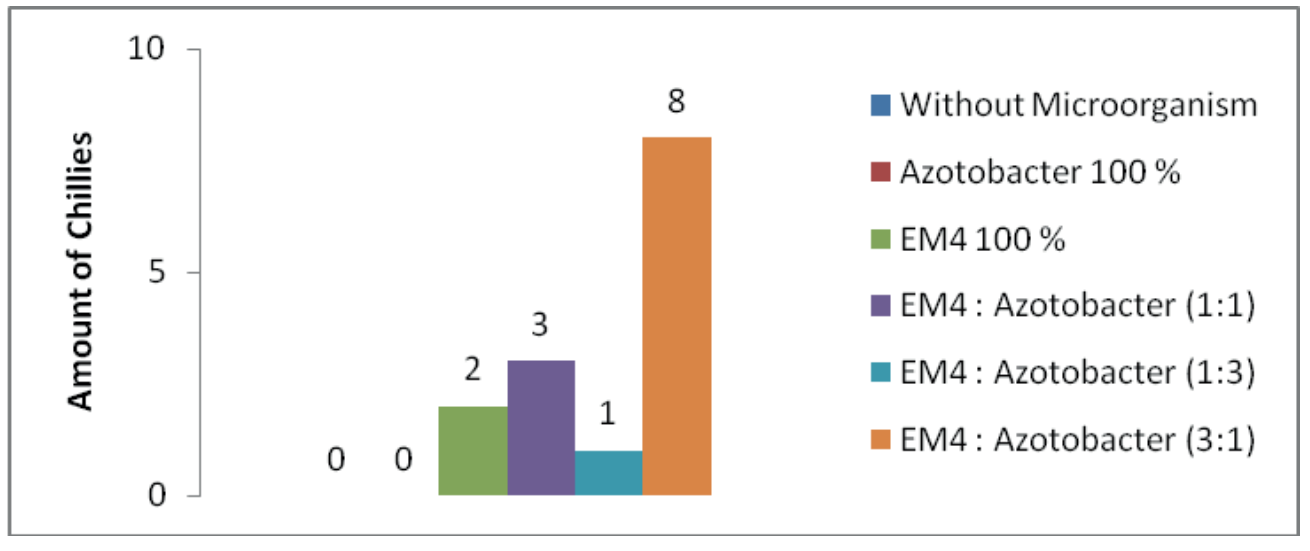

Figure 9: Graphic of the ammount of harvested chillies for $20 \mathrm{~d}$.

Figure 8 shows that the most harvested tomatoes given by compost with variable 3:1 (v/v) EM4:Azotobacter which equals to two tomatoes.

The comparison between a addition variable of EM4 activator and Azotobacter from the amount of harvested chilies for $20 \mathrm{~d}$ after being given by the compost can be seen below.

Figure 16 shows that the most harvested chilies given by compost with variable 3:1 (v/v) EM4:Azotobacter equals to eight chilies.

Based on the above chart, it is clear that the variable 3:1 (v/v) of EM4:Azotobacter gives very dominant influence to the amount of harvested tomatoes and chilies. So, the result of test is consistent with the content of $\mathrm{C}, \mathrm{N}, \mathrm{P}$, and $\mathrm{K}$ which is more dominant.

The addition of compost which contains $N$ and $P$ can increase the plant growth. Phosphor which is needed to accelerate the growth of root, accelerate and strengthen the growth of plant, accelerate flowering and ripening fruit, seeds, or flowers, and can increase the production of grains. Then the content of $\mathrm{K}$ can helps the formation of proteins and carbohydrates, improve plant resistance to disease, and to improve the quality of seeds/fruit [5].

\section{Conclusion}

Corn by-product can be used as raw material for compost. The result of this experiment showed that the best compost was obtained on 3:1 of EM4 to Azotobacter with the reduction of $\mathrm{C}$ and increment of $\mathrm{N}, \mathrm{P}, \mathrm{K}$ were $0.74 \%, 151.46 \%, 147.9 \%$, and $238.42 \%$ with growth of corn was $3.75 \mathrm{~mm}$ per day, growth of green was $1.0 \mathrm{~mm}$ per day, and harvested two tomatoes and eight chilies. 


\section{References}

[1] Eka TY, Sunanto. Diversifikasi pupuk organik dalam memenuhi kebutuhan petani di Sulawesi Selatan [Diversification of organic fertilizer for farmer's needs in South Sulawesi]. Buletin o6 (2012). BPTP Sulawesi Selatan. [in Bahasa Indonesia].

[2] BPS - Badan Pusat Statistik Jawa Timur. Luas panen, produktivitas dan produksi jagung di Jawa Timur tahun 2013 [Harvest area, productivity and maize production in East Java 2013]. [Online] from https://jatim.bps.go.id/linkTabelStatis/view/id/120 [Accessed on February 20th, 2016], [in Bahasa Indonesia].

[3] Republik Indonesia. Peraturan Menteri Pertanian Republik Indonesia. No. 28/ Permentan/SR.130/5/2009 tahun 2009 tentang pupuk organik, pupuk hayati, dan pembenah tanah [Regulation of the Minister of Agriculture of the Republic of Indonesia. No. 28 / Permentan / SR.130 / 5/2009 about organic fertilizer, biological fertilizer and soil amendement)]. [Online] from https://nasih.wordpress.com/2010/06/07/permentan-no-28-th-2009-pupuk-

organikpupukhayati-dan-pembenahtanah/ (2010) [Accessed on February 2oth, 2016], [in Bahasa Indonesia].

[4] PT. Songgolangit Persada. EM4-Pertanian [EM-4 for Agriculture]. [Online] from http://em4-indonesia.com/em4-pertanian/ [Accessed on March 4th 2016], [in Bahasa Indonesia].

[5] Sutedjo, MM. Pupuk dan cara pemupukan [Fertilizer and fertilization]. Jakarta: Penerbit Rineka Cipta; 2010. p. 52 [in Bahasa Indonesia]. 